\title{
High Level Ethanol from Sugar Cane Molasses by a New Thermotolerant Saccharomyces cerevisiae Strain in Industrial Scale
}

\author{
M. Fadel, ${ }^{1}$ Abeer A. Keera, ${ }^{1}$ Foukia E. Mouafi, ${ }^{2}$ and Tarek Kahil ${ }^{1}$ \\ ${ }^{1}$ Microbial Chemistry Department, National Research Center, Dokki, Cairo, Egypt \\ ${ }^{2}$ Genetic Engineering and Biotechnology Division, Microbial Biotechnology Department, National Research Center, Dokki, Cairo, Egypt
}

Correspondence should be addressed to M. Fadel; mfadel54@yahoo.com

Received 19 August 2013; Accepted 20 October 2013

Academic Editor: Triantafyllos Roukas

Copyright (C) 2013 M. Fadel et al. This is an open access article distributed under the Creative Commons Attribution License, which permits unrestricted use, distribution, and reproduction in any medium, provided the original work is properly cited.

\begin{abstract}
A new local strain of S. cerevisiae F-514, for ethanol production during hot summer season, using Egyptian sugar cane molasses was applied in Egyptian distillery factory. The inouluum was propagated through $300 \mathrm{~L}, 3 \mathrm{~m}^{3}$, and $12 \mathrm{~m}^{3}$ fermenters charged with diluted sugar cane molasses containing $4 \%-5 \%$ sugars. The yeast was applied in fermentation vessels $65 \mathrm{~m}^{3}$ working volume to study the varying concentrations of urea, DAP, orthophosphoric acid (OPA), and its combinations as well as magnesium sulfate and inoculum size. The fermenter was allowed to stay for a period of 20 hours to give time for maximum conversion of sugars into ethanol. S. cerevisiae F-514 at molasses sugar level of $18 \%(\mathrm{w} / \mathrm{v})$, inoculum size of $20 \%(\mathrm{v} / \mathrm{v})$ cell concentration of $3.0 \times 10^{8} / \mathrm{mL}$, and combinations of urea, diammonium phosphate (DAP), orthophosphoric acid (OPA), and magnesium sulfate at amounts of 20, 10, 5 , and $10 \mathrm{~kg} / 65 \mathrm{~m}^{3}$ working volume fermenters, respectively, supported maximum ethanol production $(9.8 \%$, v/v), fermentation efficiency (FE) $88.1 \%$, and remaining sugars (RS) $1.22 \%$. The fermentation resulted $13.4 \mathrm{~g}$ dry yeast/L contained $34.6 \%$ crude protein and $8.2 \%$ ash. By selecting higher ethanol yielding yeast strain and optimizing, the fermentation parameters both yield and economics of the fermentation process can be improved.
\end{abstract}

\section{Introduction}

Yeast selection for fuel ethanol production over the past two decades, most bioethanol related researches in developing tropical countries have focused primarily on the isolation of local Saccharomyces yeasts and their use for industrial ethanol production [1-6]. Yeasts have been isolated from many sources for industrial purposes. Such sources include cashew, apple juice [7-9], and fermenting cassava tubers [10] among others. Despite the evolving trend of using bacteria for ethanol production, yeast is still the primary choice for fermentation [11]. Yeasts are used in the fermentative production of ethanol, alcoholic beverages, baking products, protein, and vitamin supplements in human and animal diets as well as in the production of single cell proteins. However, efforts to characterize these yeasts have fallen short of expectation. In the assessment of yeasts of the genus Saccharomyces for economic and efficient ethanologenic processes, certain specific physiological properties are important and required. These include good tolerance to high concentrations of ethanol, sugars, and acids as well as high osmotic pressure [12-16]. Also good flocculation/sedimentation ability depending on process requirements as well as good invertase activity and excellent specific ethanol productivity is important characteristics of yeasts capable of converting sucrose to ethanol [17]. This paper reports the results of a study based on the comparative analysis of ethanol production along with byproducts commercial yeast strains in a local distillery of Egypt.

\section{Material and Methods}

2.1. Sugarcane Molasses. Sugarcane molasses procured by Egyptian Sugar and Integrated Industries Company is used as carbon source for ethanol production in the Distillation Factories, El-Hawamdia, Giza, Egypt. 
2.2. Yeast Strain. Saccharomyces cerevisiae F-514, which isolated by the first author was obtained from Microbial Chemistry Lab. National Research Centre, Dokki, Cairo Egypt.

2.3. Inoculums Preparation. Sterilized $500 \mathrm{ml}$ capacity conical flasks each contained $200 \mathrm{ml}$ of medium containing $(\mathrm{g} / \mathrm{L})$ malt extract, 3, yeast extract, 3, peptone, 5 and sucrose, 30 was steam sterilized at $121^{\circ} \mathrm{C}$ for 15 minutes. Cooled to room temperature, then inoculated with a loop of yeast strain $S$. cerevisiae F-514 and incubated statically at $34^{\circ} \mathrm{C}$ for $24 \mathrm{hrs}$, then transferred to flat round bottom flasks of $2 \mathrm{~L}$ capacity each containing $1 \mathrm{~L}$ sterilized molasses diluted to $4-5 \%(\mathrm{w} / \mathrm{v})$ sugar content supplemented with $0.4 \%$ DAP and $0.2 \%$ yeast extract. The inoculated flat round bottom flasks are incubated statically at $34^{\circ} \mathrm{C}$ for $24 \mathrm{hrs}$.

Yeast cultures were prepared in separate seed fermenters of $300 \mathrm{~L}$ capacity. Molasses diluted to $4-5 \%(\mathrm{w} / \mathrm{v})$ sugars content was supplemented with Urea $(0.1 \%$, and $0.2 \%$ DAP $\mathrm{w} / \mathrm{v}, \mathrm{pH}$ of the medium was adjusted to 4.6 (Pre optimized) using diluted $\mathrm{NaOH}$ and diluted $\mathrm{H}_{2} \mathrm{SO}_{4}$. The medium was steam sterilized. After cooling to $32^{\circ} \mathrm{C} \pm 2$ two flat round bottom flasks from above inoculum strain of yeast were added and the seed fermenters were aerated to facilitate the growth of yeasts. At the end of first stage of 16 hours of continuous circulation, sample withdrawn from the sample valve was subjected to analyses to get $3.0 \times 10^{8}$ cells per $\mathrm{mL}$. The cultures were transferred to second stage of propagation in individual steam-desterilized ( 45 minutes) fermenter of $3 \mathrm{~m}^{3}$ capacity, contained the same essential nutrients of seed fermenter, the fermentation was continued for about 14 hours. In the third stage the yeast cultures from the second stage fermenters were transferred to the propagation tanks of $12 \mathrm{~m}^{3}$ capacities with $10 \mathrm{~m}^{3}$ working volume containing the same above medium. The fermentation was continued till reducing sugars contents below $1 \%$ and ethanol content in the range of $3.2-3.8 \%(\mathrm{v} / \mathrm{v})$, having $3.0 \times 10^{8}$ cells $/ \mathrm{mL}$ were prepared for use in industrial fermentation of molasses to ethanol production.

2.4. Fermentation Process. Batch culture system was employed for optimization of fermentation parameters for $S$. cerevisiae F-514 strain. The yeast culture was transferred to fermenters having working volume of $65 \mathrm{~m}^{3}$. Initially a bed of $25 \%$ volume was made by $5 \mathrm{~m}^{3}$ yeast culture $3.0 \times$ $10^{8}$ cells $/ \mathrm{mL}$ at the bottom of fermenter in molasses medium contained 5-6\% sugars, supplemented with the parameters to be optimized, but afterwards feeding of diluted molasses to gave final concentration $18 \%(\mathrm{w} / \mathrm{v})$ sugars was fed to the fermenters to enable yeast cells to utilize sugars in the molasses for conversion into ethanol. Batch of molasses was adjusted, so that fermenters vessels were filled to $80 \%$ working capacity $\left(65 \mathrm{~m}^{3}\right)$ and then stayed to ferment for a period of 20 hours to allow the maximum conversion of sugars into ethanol. After 20 hours, the samples collected through sample valves were analyzed for ethanol content, residual sugars, viable cell count, and yeast biomass yield.

2.5. Process Optimization. During fermentation stage, all the parameters to be optimized were varied (Urea, diammonium phosphate (DAP), Orthophosphoric acid (OPA), magnesium sulfate and inoculum size). During optimization, temperature and $\mathrm{pH}$ were not adjusted.

Cell count optimization was performed by using yeast cell counts $3.0 \times 10^{8}$ cells $/ \mathrm{mL}$ inoculum.

Varying concentrations of urea, 10, 15, 20, 25, and $30 \mathrm{~kg} / 65 \mathrm{~m}^{3}$ were added to the fermentation media in $65 \mathrm{~m}^{3}$ working volume fermenter inoculated with $10 \% \mathrm{v} / \mathrm{v}$ yeast inoculum cell counts $300 \times 10^{6}$ cells $/ \mathrm{mL}$.

Varying concentrations of $\operatorname{ADP}(5,10,15$, and $20 \mathrm{~kg} /$ $65 \mathrm{~m}^{3}$ ) were added to the fermentation medium under above optimized urea level.

Varying concentrations of orthophosphoric acid (OPA) $\left(5,10,15\right.$, and $\left.20 \mathrm{~kg} / 65 \mathrm{~m}^{3}\right)$ were added to the fermentation media in $65 \mathrm{~m}^{3}$ working volume fermenter under optimized urea level.

Combinations of urea, ADP, and OPA, that is, 20, 10, and $5 \mathrm{~kg} / 65 \mathrm{~m}^{3}$, respectively, were added to the fermentation medium.

Varying concentrations of magnesium sulfate $(5,10,15$, and $20 \mathrm{~kg} / 65 \mathrm{~m}^{3}$ ) were added to the fermentation medium in $65 \mathrm{~m}^{3}$ working volume fermenter under the applied concentrations of urea, ADP, and OPA.

Varying sizes of inoculum $(5,10,15,20$, and $25 \mathrm{v} / \mathrm{v} \%)$ were used to inoculate the respective fermentation fermenters under optimized parameters of urea, DAP, OPA, and magnesium sulfate to investigate the effect of inoculum size on ethanol production.

Varying concentrations of molasses under optimized parameters of Urea, DAP, OPA and magnesium sulfate and inoculum size to investigate the effect of molasses concentrations on ethanol production on time.

\subsection{Analytical Procedures}

2.6.1. Determination of Sugar Concentration. The sugar concentration was determined by rapid method. The $5 \mathrm{~mL}$ of fermented sample was taken and dissolved in $100 \mathrm{~mL}$ of distilled water and mixed with $5 \mathrm{~mL}$ of conc. HCL acid and is heated at $70^{\circ} \mathrm{C}$ for a period of $10 \mathrm{~min}$. The obtained sample was neutralized by adding $\mathrm{NaOH}$ and it was prepared to $1000 \mathrm{~mL}$ and taken into burette solution. The $5 \mathrm{~mL}$ of Fehling $A$ and $5 \mathrm{~mL}$ of Fehling $B$ were taken and mixed with 10 to $15 \mathrm{~mL}$ of distilled water in a conical flask and methylene blue indicator was added. The conical flask solution was titrated with burette solution in boiling conditions until disappearance of blue color. The sugar concentration was calculated by using the formula given below: Sugar Concentration $(\mathrm{gm} / \mathrm{L})$ $=[($ Dilution factor $\times$ Fehling factor $) /$ Titrate value $] \times 100$.

2.6.2. Ethanol Content. Ethanol content of the fermented samples was measured with ebulliometer approved in distillation factories.

2.6.3. Fermentation Efficiency. Fermentation efficiency was calculated as the ethanol yield divided by the theoretical yield multiply by 100 . 
TABLE 1: Effect of varying concentrations of urea (as nitrogen source) on ethanol production by S. cerevisiae F-514 using sugarcane molasses.

\begin{tabular}{lccccccc}
\hline Urea $\mathrm{kg} / 65 \mathrm{~m}^{3}$ & Initial $\mathrm{pH}$ & $\mathrm{EOH} \% \mathrm{v} / \mathrm{v}$ & $\mathrm{RS} \%$ & $\mathrm{FE} \%$ & Final pH & Viable yeast cells $\times 10^{8}$ & Yeast yield $(\mathrm{g} / \mathrm{L})$ \\
\hline 10 & 4.6 & 7.8 & 3.11 & 70.1 & 4.9 & 2.55 & 10.4 \\
15 & 4.6 & 8.1 & 2.85 & 72.8 & 5.0 & 2.75 & 10.8 \\
20 & 4.7 & 8.3 & 2.60 & 74.6 & 5.1 & 2.90 & 11.4 \\
25 & 4.7 & 8.4 & 2.46 & 75.5 & 5.2 & 2.90 & 11.4 \\
30 & 4.8 & 8.2 & 2.66 & 73.7 & 5.4 & 2.85 & 11.2 \\
\hline
\end{tabular}

TABLE 2: Effect of varying concentrations of DAP on ethanol production by S. cerevisiae F-514 using sugarcane molasses.

\begin{tabular}{lccccccc}
\hline $\mathrm{DAP} \mathrm{kg} / 65 \mathrm{~m}^{3}$ & Initial $\mathrm{pH}$ & $\mathrm{EOH} \% \mathrm{v} / \mathrm{v}$ & $\mathrm{RS} \%$ & $\mathrm{FE} \%$ & Final $\mathrm{pH}$ & ${\text { Viable yeast cells } \times 10^{8}}^{\text {Yeast yield }(\mathrm{g} / \mathrm{L})}$ \\
\hline 5 & 4.7 & 8.5 & 2.16 & 76.4 & 5.2 & 2.95 & 11.1 \\
10 & 4.7 & 8.7 & 1.96 & 78.2 & 5.2 & 3.00 & 11.4 \\
15 & 4.8 & 8.9 & 1.66 & 80.1 & 5.3 & 3.10 & 11.8 \\
20 & 4.8 & 8.9 & 1.64 & 80.1 & 5.4 & 3.10 & 11.6 \\
\hline
\end{tabular}

Cell count was determined using microscope with the help of haemocytometer. Cell viability was checked by using methylene blue indicator. The dead cells were stained with blue indicator while viable cells remained uncolored.

2.6.4. Analysis of Dry Yeast Yield. Crude protein was measured by micro-Kejldahel method [18]. Ash was carried out on dried sample at $105^{\circ} \mathrm{C}$, by ignition 3 samples each $50 \mathrm{~g}$ in muffle furnace at $800^{\circ} \mathrm{C}$ for 5 hours, and the residual ash was calculated as \% from the dried initial weigh [19]. Cell dry weight was determined using $20 \mathrm{ml}$ samples of the yeast culture collected by centrifugation $\left(10 \mathrm{~min}\right.$ at $\left.7500 \mathrm{xg}, 4^{\circ} \mathrm{C}\right)$ in a pre-weighed dried tube and then washed with $20 \mathrm{ml}$ of distilled water. The tube was dried overnight at $105^{\circ} \mathrm{C}$ and weighed again.

\section{Results and Discussion}

3.1. Effect of Varying Concentrations of Urea (as Nitrogen Source). Varying concentrations of urea were added as nitrogen supplement for yeast growth (Table 1). Results showed that cell growth and ethanol yield increased with urea addition and $25 \mathrm{~kg}$ urea $/ 65 \mathrm{~m}^{3}$ fermenter working volume gave maximum ethanol yield $(\mathrm{EOH})$ of $8.4 \% \mathrm{v} / \mathrm{v}$ with remaining sugar (RS) $2.46 \%$, fermentation efficiency (FE) $75.5 \%$, yeast viable cells $2.90 \times 10^{8} / \mathrm{mL}$, and dry yeast biomass $11.4 \mathrm{~g} / \mathrm{L}$. Nitrogen deficiency slows down yeast growth and the fermentation [20-22], possibly due to the inhibition of the synthesis of protein transporting sugars through the cell membrane to the interior of the cells [23, 24]. It has been shown that adequate nitrogen increases yeast growth provided that the other essential yeast nutrient is not lacking [25-27].

3.2. Effect of Varying Concentrations of DAP. Varying concentrations of DAP were used as phosphorus and supplementary nitrogen source to promote yeast growth and increase ethanol production (Table 2). At DAP concentration of $15 \mathrm{~kg} /$ fermenter $65 \mathrm{~m}^{3}$ working volume, S. cerevisiae F-514 produced $8.9 \%(\mathrm{v} / \mathrm{v})$ ethanol with RS, $1.66 \%$, FE $80.1 \%$ final cell count $3.10 \times 10^{8} / \mathrm{mL}$, and dry yeast cells $11.8 \mathrm{~g} / \mathrm{L}$.

3.3. Effect of Varying Concentrations of OPA. Phosphate limitation has been shown to affect cell growth and biomass formation as well as directly affecting fermentation rate [28, 29]. Varying concentrations of OPA were used as phosphorus source under the optimum amount of urea to promote yeast growth and increase ethanol production (Table 3). At OPA concentration of $15 \mathrm{~kg} /$ fermenter $65 \mathrm{~m}^{3}$ working volume, $S$. cerevisiae F-514 produced $9.1 \%(\mathrm{v} / \mathrm{v})$ ethanol with FE $81.8 \%$, remaining sugars, 1.32 , final cell count $3.40 \times 10^{8} / \mathrm{mL}$, and dry yeast cells $11.7 \mathrm{~g} / \mathrm{L}$.

3.4. Effect of Combination of Urea, of DAP and OPA. Date presented in Table 4 Showed that combination from 20, 10, and $5 \mathrm{~kg}$ of urea. DAP and OPA, respectively $/ 65 \mathrm{~m}^{3}$ medium more suitable for ethanol yield comparable with urea plus DAP or urea plus OPA (Tables 2 and 3 ) as produced 9.3\% (v/v) ethanol with FE $83.6 \%$, remaining sugars, 1.32 , final cell count $3.45 \times 10^{8} / \mathrm{mL}$ and dry yeast cells $12.1 \mathrm{~g} / \mathrm{L}$. Nitrogen and phosphorus are the main nutritional requirements for the yeast growth and maximum ethanol production efficiency. Although molasses contains most of the nutrients required for yeast growth, generally nitrogen and phosphate are added to enhance yeast growth and ethanol production [30]. For optimum yeast efficiency in molasses medium, urea was used as nitrogen source and OPA was used as phosphate source. Phosphorus has the major role in the glycolysis cycle in the yeast cell. Extensive studies were previously performed to optimize the nitrogen and phosphorous sources and other supplements [31]. Higher ethanol production has also previously been reported with urea, phosphoric acid, making the process very economical [27]. Phosphate limitation has been shown to affect cell growth and biomass formation as well as directly affecting fermentation rate $[28,29]$.

3.5. Effect of Varying Concentrations of Magnesium. Varying concentrations of magnesium sulfate were supplement under 
TABLE 3: Effect of varying concentrations of OPA on ethanol production by S. cerevisiae F-514 using sugarcane molasses in batch culture.

\begin{tabular}{lccccccc}
\hline OPA kg/65 m & Initial $\mathrm{pH}$ & EOH $\%$ v/v & RS\% & FE\% & Final $\mathrm{pH}$ & ${\text { Viable yeast cells } \times 10^{8}}^{\text {Yeast yield }(\mathrm{g} / \mathrm{L})}$ \\
\hline 5 & 4.7 & 8.6 & 1.72 & 77.3 & 4.9 & 3.00 & 11.2 \\
10 & 4.7 & 8.8 & 1.56 & 79.1 & 4.8 & 3.20 & 1.4 \\
15 & 4.8 & 9.1 & 1.32 & 81.8 & 4.8 & 3.40 & 11.7 \\
20 & 4.8 & 9.0 & 1.46 & 81.7 & 4.6 & 3.20 & 11.6 \\
\hline
\end{tabular}

TABLE 4: Effect of combination of urea, of DAP, and OPA on ethanol production by S. cerevisiae F-514 using sugarcane molasses.

\begin{tabular}{lccccccc}
\hline $\mathrm{kg} / 65 \mathrm{~m}^{3}$ & Initial $\mathrm{pH}$ & $\mathrm{EOH} \% \mathrm{v} / \mathrm{v}$ & $\mathrm{RS} \%$ & $\mathrm{FE} \%$ & Final $\mathrm{pH}$ & Viable yeast cells $\times 10^{8}$ & Yeast yields $(\mathrm{g} / \mathrm{L})$ \\
\hline${\text { Urea } 20^{*}}^{*}$ & 4.7 & 8.3 & 2.6 & 74.6 & 51 & 2.90 & 11.4 \\
${ }^{*}+\mathrm{DAP} 10^{* *}$ & 4.7 & 8.7 & 1.74 & 78.2 & 5.2 & 3.15 & 11.8 \\
${ }^{* *}+$ OPA 5 & 4.8 & 9.3 & 1.32 & 83.6 & 5.1 & 3.45 & 12.1 \\
\hline
\end{tabular}

TABLE 5: Effect of varying concentrations of magnesium sulfate on ethanol production by S. cerevisiae F-514 using sugarcane molasses in batch culture.

\begin{tabular}{lccccccc}
\hline Magnesium sulfate $\mathrm{kg} / 65 \mathrm{~m}^{3}$ & Initial $\mathrm{pH}$ & $\mathrm{EOH} \% \mathrm{v} / \mathrm{v}$ & $\mathrm{RS} \%$ & $\mathrm{FE} \%$ & Final $\mathrm{pH}$ & ${\text { Viable yeast cell } \times 10^{8}}^{\text {Yeast yield }(\mathrm{g} / \mathrm{L})}$ \\
\hline 5 & 4.7 & 9.5 & 1.40 & 85.4 & 4.8 & 3.60 & 12.4 \\
10 & 4.7 & 9.6 & 1.32 & 86.3 & 4.8 & 3.60 & 12.4 \\
15 & 4.8 & 9.6 & 1.36 & 87.1 & 5.0 & 3.60 & 12.2 \\
20 & 4.8 & 9.5 & 1.40 & 85.4 & 5.0 & 3.55 & 12.1 \\
\hline
\end{tabular}

TABLE 6: Effect of varying inoculum size on ethanol production by S. cerevisiae F-514 using sugarcane molasses.

\begin{tabular}{lccccccc}
\hline Inoculum size\% (v/v) & Initial $\mathrm{pH}$ & $\mathrm{EOH} \% \mathrm{v} / \mathrm{v}$ & $\mathrm{RS} \%$ & $\mathrm{FE} \%$ & Final pH & Viable yeast cell $\times 10^{8}$ & Yeast yield $(\mathrm{g} / \mathrm{L})$ \\
\hline 5 & 4.7 & 9.4 & 1.71 & 84.5 & 4.8 & 3.15 & 12.2 \\
10 & 4.7 & 9.6 & 1.36 & 86.3 & 4.8 & 3.60 & 12.4 \\
15 & 4.8 & 9.7 & 1.28 & 87.2 & 5.0 & 3.75 & 13.1 \\
20 & 4.8 & 9.8 & 1.22 & 88.1 & 5.2 & 3.80 & 13.2 \\
25 & 4.8 & 9.6 & 1.64 & 86.3 & 5.2 & 395 & 13.6 \\
\hline
\end{tabular}

the above optimized levels of urea, DAP and OPA for yeast growth (Table 5). Results showed that cell growth and ethanol yield and fermentation efficiency increased with magnesium sulfate addition and $10 \mathrm{~kg}$ concentration gave maximum ethanol content of $9.6 \%(\mathrm{v} / \mathrm{v})$ ethanol with remaining sugars, 1.32 , final cell count $3.60 \times 10^{8} / \mathrm{m}$, and yeast yield $12.4 \mathrm{~g} / \mathrm{L}$. Deficiencies and imbalances in minerals and cations serving as cofactors for glycolytic and other enzymatic reactions can result in fermentation arrest [32]. Magnesium plays a key role in metabolic control, growth and cell proliferation, glycolytic pathway, and subsequently ethanol production [33].

3.6. Effect of Varying Inoculum Size. Ethanol yield and production of coproducts have a major relationship during ethanol fermentation. Extensive studies have been carried out to investigate the effect of yeast inoculation rate to help the yeast cells overcome the bacterial cells on the basis of size and number. Effect of varying inoculum sizes on ethanol yield was studied under optimized parameters, urea $20 \mathrm{~kg}$, DAP $10 \mathrm{~kg}$, OPA $5 \mathrm{~kg}$, and magnesium sulfate $10 \mathrm{~kg} / 65 \mathrm{~m}^{3}$ working volume fermenter. Maximum ethanol content was found at an inoculation rate of $20 \% \mathrm{v} / \mathrm{v}$. Results have shown that at $20 \%$ inoculation rate, ethanol content was $9.8 \%(\mathrm{v} / \mathrm{v})$ (Table 6).
In brewing, higher yeast inoculation rates cause attenuation to initiate the process more rapidly and reduce viability losses that occur immediately after pitching. In a previous study, the ethanol yield increased with increasing inoculum size and yield of methanol or aldehyde was the lowest at inoculum size above $30 \%$ [34] and gave optimum ethanol content $9.8 \% \mathrm{v} / \mathrm{v}$. The remaining sugars were $1.22 \%$, final viable cell count $3.60 \times$ $10^{8} / \mathrm{mL}$, and yeast yield $13.2 \mathrm{~g} / \mathrm{L}$.

3.7. Effect of Varying Sugarcane Molasses Concentrations. Varying doses of sugar cane molasses contained varying sugars concentration were applied to study the effect of sugar level in fermentation medium on the ethanol yield on time under the above optimized levels of urea, DAP. OPA, magnesium sulfate and inoulum size (Table 7). Results show that most suitable sugars concentration for ethanol production by S. cerevisiae F-514 was $18 \%(\mathrm{w} / \mathrm{v})$ gave high ethanol yield $9.8 \%(\mathrm{v} / \mathrm{v})$, FE $88.1 \%$. RS $1.22 \%$ and applied low or above other sugar concentrations not economic. Increase in medium sugar level is believed to affect the relative proportion of total medium sugar converted to alcohol [17, $35,36]$. The decline in yeast ethanol productivity at high medium sucrose levels as observed in this study is in close 
TABLE 7: Effect of varying sugarcane molasses concentrations on time on ethanol production by S. cerevisiae F-514.

\begin{tabular}{|c|c|c|c|c|c|c|c|c|c|c|c|}
\hline \multirow{3}{*}{ Sugar\% (w/v) } & \multicolumn{10}{|c|}{ Fermentation time (hrs) } & \multirow{3}{*}{$\mathrm{FE} \%$} \\
\hline & \multicolumn{2}{|l|}{16} & \multicolumn{2}{|l|}{18} & \multicolumn{2}{|c|}{20} & \multicolumn{2}{|l|}{22} & \multicolumn{2}{|l|}{24} & \\
\hline & $\mathrm{EOH} \%(\mathrm{v} / \mathrm{v})$ & $\mathrm{RS} \%$ & $\mathrm{EOH} \%(\mathrm{v} / \mathrm{v})$ & RS\% & $\mathrm{EOH} \%(\mathrm{v} / \mathrm{v})$ & RS\% & $\mathrm{EOH} \%(\mathrm{v} / \mathrm{v})$ & RS\% & $\mathrm{EOH} \%(\mathrm{v} / \mathrm{v})$ & RS\% & \\
\hline 16 & 8.2 & 1.34 & 8.6 & 1.32 & 8.6 & 1.22 & 8.5 & 1.22 & 8.5 & 1.22 & 86.9 \\
\hline 17 & 8.7 & 1.46 & 8.9 & 1.28 & 9.1 & 1.28 & 9.3 & 1.28 & 8.8 & 1.28 & 86.5 \\
\hline 18 & 9.4 & 1.68 & 9.9 & 1.22 & 9.8 & 1.22 & 9.8 & 1.22 & 9.8 & 1.22 & 88.1 \\
\hline 19 & 9.2 & 1.86 & 9.4 & 1.56 & 9.7 & 1.96 & 9.8 & 1.74 & 9.8 & 1.74 & 83.4 \\
\hline 20 & 8.9 & 3.45 & 9.4 & 2.84 & 9.7 & 2.96 & 9.8 & 2.86 & 9.8 & 2.86 & 79.2 \\
\hline 21 & 8.2 & 4.65 & 8.4 & 3.55 & 9.4 & 3.20 & 9.6 & 2.20 & 9.6 & 2.20 & 73.9 \\
\hline 22 & 7.8 & 6.24 & 8.2 & 5.42 & 8.6 & 3.22 & 9.2 & 3.24 & 9.4 & 3.24 & 69.1 \\
\hline
\end{tabular}

agreement with the finding of several other researchers of the Saccharomyces genus in medium of high osmotic pressures $[35,37,38]$.

3.8. Chemical Composition of Yeast Yield. The chemical composition of the yeast on basis of dry weight was protein $34.6 \%$ and ash $8.2 \%$. Our study was applied in distillery factory distilled about $1600 \mathrm{~m}^{3}$ daily producing about 20 tons of fodder yeast. Yeasts are a rich source of protein and B-complex vitamins. They have been used successfully as a complementary protein source in fish diet [39]. Also, they have been used as a supplement in animals feed to compensate for the amino acid and vitamin deficiencies of cereals and are recommended as a substitute for soybean oil in diets for fowl [40], and flavor enhancers can be produced from yeasts [41]. In addition, they are considered a cheaper dietary supplement as they are easily produced on an industrial level [42].

The results of our study showed that under optimum conditions. However, optimization of process parameters improved ethanol production by the local yeast strains of S. cerevisiae F-514 in Egyptian Distillation Factories without needing to cooling system that make ethanol production more economic. The obtained ethanol concentration in this study was higher than that obtained by other workers studied the optimization fermentation conditions for producing ethanol from cane molasses under industrial scale by batch or fed batch fermentation using other different yeast strains, as it were $7.9 \%(\mathrm{v} / \mathrm{v})$ Abd El Fattah et al. [6], 8.6\% (v/v) Arshad et al. [34] and 8.2\% (v/v) Mukhtar et al. [43].

\section{Acknowledgments}

The authors deeply thanks the engineering H. K. Hassan Chairman \& Managing Director of Egyptian Sugar \& Integrated Industry Company. Also all thanks to Chairman and members of Hawamdia Distillation Factories.

\section{References}

[1] B. Bulawayo, J. M. Bvochora, M. I. Muzondo, and R. Zvauya, "Ethanol production by fermentation of sweet-stem sorghum juice using various yeast strains," World Journal of Microbiology and Biotechnology, vol. 12, no. 4, pp. 357-360, 1996.
[2] L. I. Ezeogu and A. C. Emeruwa, "High level ethanol-tolerant Saccharomyces from Nigerian palm wine," Biotechnology Letters, vol. 15, no. 1, pp. 83-86, 1993.

[3] L. I. Ezeogu and B. N. Okolo, "Effect of molasses concentration and medium supplementation on the adaptability and viability of a high level ethanol-tolerant palm-wine Saccharomyces isolate," Biotechnology Letters, vol. 16, no. 1, pp. 95-100, 1994.

[4] B. N. Okolo, J. R. Johnston, and D. R. Berry, "Toxicity of ethanol, $\mathrm{n}$-butanol and iso-amyl alcohol in Saccharomy cescerevisiae when supplied separately and in mixtures," Biotechnology Letters, vol. 9, no. 6, pp. 431-434, 1987.

[5] S. Sefa-Dedeh, A. I. Sanni, G. Tetteh, and E. Sakyi-Dawson, "Yeasts in the traditional brewing of pito in Ghana," World Journal of Microbiology and Biotechnology, vol. 15, no. 5, pp. 593$597,1999$.

[6] W. R. Abdel Fattah, M. Fade, P. Nigam, and L. M. Banat, "Isolation of thermotolerant ethanologenic yeasts and use of selected strains in industrial scale fermentation in an Egyptian distillery," Biotechnology and Bioengineering, vol. 68, no. 5, pp. 531-535, 2000.

[7] A. Osho, "Ethanol and sugar tolerance of wine yeasts isolated from fermenting cashew apple juice," African Journal of Biotechnology, vol. 4, no. 7, pp. 660-662, 2005.

[8] E. E. T. Bechem, C. Omoloko, D. Nwaga, and V. P. K. Titanji, "Characterization of palm wine yeasts using osmotic, ethanol tolerance and the isozyme polymorphism of alcohol dehydrogenase," African Journal of Biotechnology, vol. 6, no. 14, pp. 1715$1719,2007$.

[9] I. N. Nwachukwu, V. I. Ibekwe, R. N. Nwabueze, and B. N. Anyanwu, "Characterisation of palm wine yeast isolates for industrial utilisation," African Journal of Biotechnology, vol. 5, no. 19, pp. 1725-1728, 2006.

[10] O. B. Oyewole and S. A. Odunfa, "Microbiological studies on cassava fermentation for "lafun" production," Food Microbiology, vol. 5, no. 3, pp. 125-133, 1988.

[11] Chandra, Yeast Strain Selection, Bioprocess Technology Series, Marcel Dekker, New York, NY, USA, 2003.

[12] V. Ansanay-Galeote, B. Blondin, S. Dequin, and J. Sablayrolles, "Stress effect of ethanol on fermentation kinetics by stationaryphase cells of Saccharomyces cerevisiae," Biotechnology Letters, vol. 23, no. 9, pp. 677-681, 2001.

[13] T. Benitez, L. Del Castillo, A. Aguilera, J. Conde, and E. CerdaQlmedo, "Selection of wine yeasts for growth and fermentation in the presence of ethanol and sucrose," Applied and Environmental Microbiology, vol. 45, no. 5, pp. 1429-1436, 1983. 
[14] L. I. Ezeogu and B. N. Okolo, "Sedimentation characteristics and effect of molasses concentration and medium supplementation on the ethanol productivity of an ethanol tolerance palm wine Saccharomyces," Biotechnology Letters, vol. 16, no. 1, pp. 101-106, 1994.

[15] B. N. Okolo, A. N. Moneke, C. U. Anyanwu, L. I. Ezeogu, and G. N. Aligwekwe, "On the $\mathrm{pH}$ and osmotic tolerance of high ethanol tolerant palm wine Saccharomyces cerevisiae yeast isolates," Journal of Biological Research and Biotechnology, vol. 2, no. 1, pp. 1-7, 2004.

[16] G. Stewart, J. Panchal, I. Russel, and M. Sills, "Biology of ethanol producing microorganisms," Critical Reviews in Biotechnology, vol. 1, article 161, 1984.

[17] J. Jimenez and T. Benitez, "Characterization of wine yeasts for ethanol production," Applied Microbiology and Biotechnology, vol. 25, no. 2, pp. 150-154, 1986.

[18] AOAC, Official Methods of Analysis of the Association of Official Analytical Chemists, vol. 1, AOAC, Washington, DC, USA, 11th edition, 1970.

[19] AOAC, Official Methods of Analysis of the Association of Official Analytical Chemists, AOAC, Washington, DC, USA, 1980.

[20] P. R. Monk, "Effect of nitrogen and vitamin on yeast growth and rate of fermentation of Rine Riesling grape juice," Food Technology Australia, vol. 34, pp. 328-332, 1982.

[21] V. Jiranek, P. Langridge, and P. A. Henschke, "Amino acid and ammonium utilization by Saccharomyces cerevisiae wine yeasts from a chemically defined medium," The American Journal of Enology and Viticulture, vol. 46, no. 1, pp. 75-83, 1995.

[22] C. E. Butzke and B. C. Dukes, Detection and Consequences of Nitrogen Deficienctes in Must, Wine Spoilage Microbiology Conference CATI Publication, 960203, California State University, Fresno, Calif, USA, 1996.

[23] J. M. Salmon, "Effect of sugar transport inactivation in Saccharomyces cerevisiae on sluggish and stuck enological fermentations," Applied and Environmental Microbiology, vol. 55, no. 4, pp. 953-958, 1989.

[24] Huang, "Amino acids profiles of commercial of grape juices and wines," The American Journal of Enology and Viticulture, vol. 42, pp. 261-267, 1991.

[25] P. A. Henschke, "Evaluation wine yeasts for improved wine quality," in Proceedings of the 7th Australian wine Industry Technical Conference, pp. 157-165, Australian Industrial publishing, Adelaide, Australia, 1990.

[26] B. Dukes, B. Goldspink, J. Elliott, and R. Frane, "Time of nitrogenous fertilization cane reduse fermentation time and improve wine quality," The American Journal of Enology and Viticulture, pp. 249-254, 1991.

[27] Z. Nofemele, P. Shukl, A. Trussler, K. Permaul, and S. Singh, "Improvement of ethanol production from sugar cane molasses through enhanced nutrient supplementation using Saccharomyces cerevisiae," Journal of Brewing and Distilling, vol. 3, no. 2, pp. 29-35, 2012.

[28] C. Gancedo and R. Serrano, "The yeast," in Metabolism and Physiology of Yeast, pp. 205-259, Academic Press, New York, NY, USA, 2nd edition, 1989.

[29] R. B. Boulton, V. L. Singlton, L. F. Bisson, and R. E. Kunkee, in Principles and Practices of Winemaking, Chapman \& Hall, New York, NY, USA, 1996.

[30] I. S. Pretorius, M. Du Toit, and P. van Rensburg, "Designer yeasts for the fermentation industry of the 21st century," Food Technology and Biotechnology, vol. 41, no. 1, pp. 3-10, 2003.
[31] S. Malherbe, F. F. Bauer, and M. Du Toit, "Understanding problem fermentations-a review," South African Journal of Enology and Viticulture, vol. 28, no. 2, pp. 169-185, 2007.

[32] K. J. Blackwell, J. M. Tobin, and S. V. Avery, "Manganese uptake and toxicity in magnesium supplemented and unsupplemented Saccharomyces cerevisiae," Applied Microbiology and Biotechnology, vol. 47, no. 2, pp. 180-184, 1997.

[33] G. M. Walker, "The roles of magnesium in biotechnology," Critical Reviews in Biotechnology, vol. 14, no. 4, pp. 311-354, 1994.

[34] M. Arshad, Z. M. Khan, K. Khalil-Ur-Rehman, F. A. Shah, and M. I. Rajoka, "Optimization of process variables for minimization of byproduct formation during fermentation of blackstrap molasses to ethanol at industrial scale," Letters in Applied Microbiology, vol. 47, no. 5, pp. 410-414, 2008.

[35] T. D’Amore, C. J. Pancha, and G. G. Stewart, "Intracellular ethanol accumulation in Saccharomyces cerevisiae during fermentation," Applied and Environmental Microbiology, vol. 54, no. 1, pp. 110-114, 1988.

[36] T. W. Nagodawithana and K. H. Steinkraus, "Influence of the rate of ethanol production and accumulation on the viability of Saccharomyces cerevisiae in 'rapid fermentation," Applied and Environmental Microbiology, vol. 31, no. 32, pp. 158-162, 1976.

[37] L. C. Basso, H. V. de Amorim, A. J. de Oliveira, and M. L. Lopes, "Yeast selection for fuel ethanol production in Brazil," FEMS Yeast Research, vol. 8, no. 7, pp. 1155-1163, 2008.

[38] E. Patrascu, G. Rapeanu, and T. Hopulele, "Current approaches toeffecient biotechnological production of ethanol," Innovative Romanina Food Biotecnology, 4, pp. 1-11, 2009.

[39] D. Ballerini and C. Thcmon, Proceedings of OAPEC Symposium on Petroprotein, Organization of Arab Petroleum Exporting Countries (OAPEC), Safat, Kuwait, 1980.

[40] B. Gohl, Tropical Feeds, FAO/Oxford Computer Journals LTD, Version 1-7, 1991.

[41] M. A. Otero, I. Guerrero, J. R. Wagner et al., "Yeast and its derivatives as ingredients in the food industry," Biotecnologia Aplicada, vol. 28, no. 4, pp. 272-275, 2011.

[42] M. E. Abd ELHalim, A. Omar, A. M. Nour, and M. G. Abd Ellatif, "Utilization yeast (Saccharomyces cerevisiae) in fish feeds," in Proceedings of the 2nd Alexandria Conference of Food Science and Technology, 1995.

[43] K. Mukhtar, M. Asgher, S. Afghan, K. Hussain, and S. Zia-UlHussnain, "Comparative study on two commercial strains of Saccharomyces cerevisiae for optimum ethanol production on industrial scale," Journal of Biomedicine and Biotechnology, vol. 2010, Article ID 419586, 5 pages, 2010. 

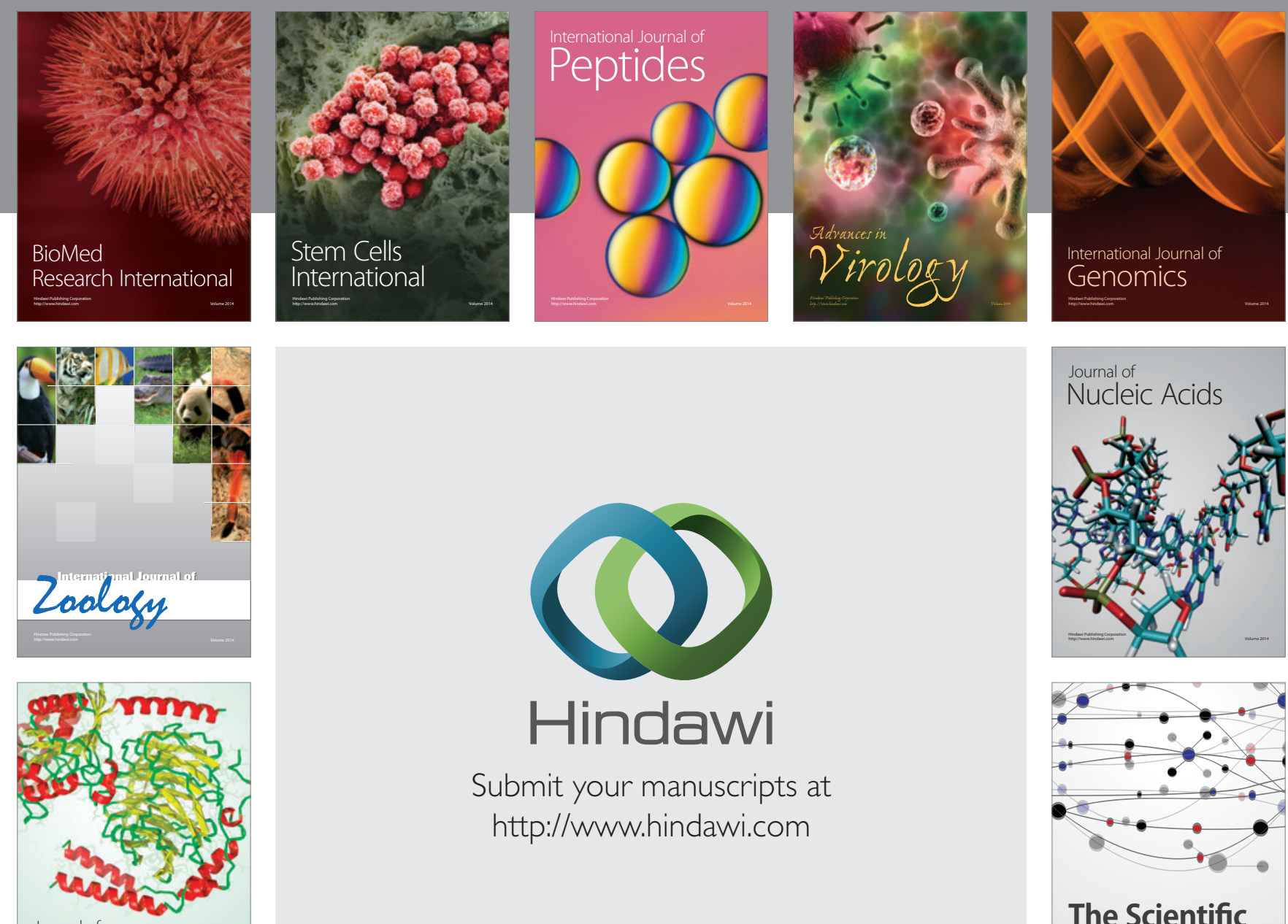

Submit your manuscripts at

http://www.hindawi.com

Journal of
Signal Transduction
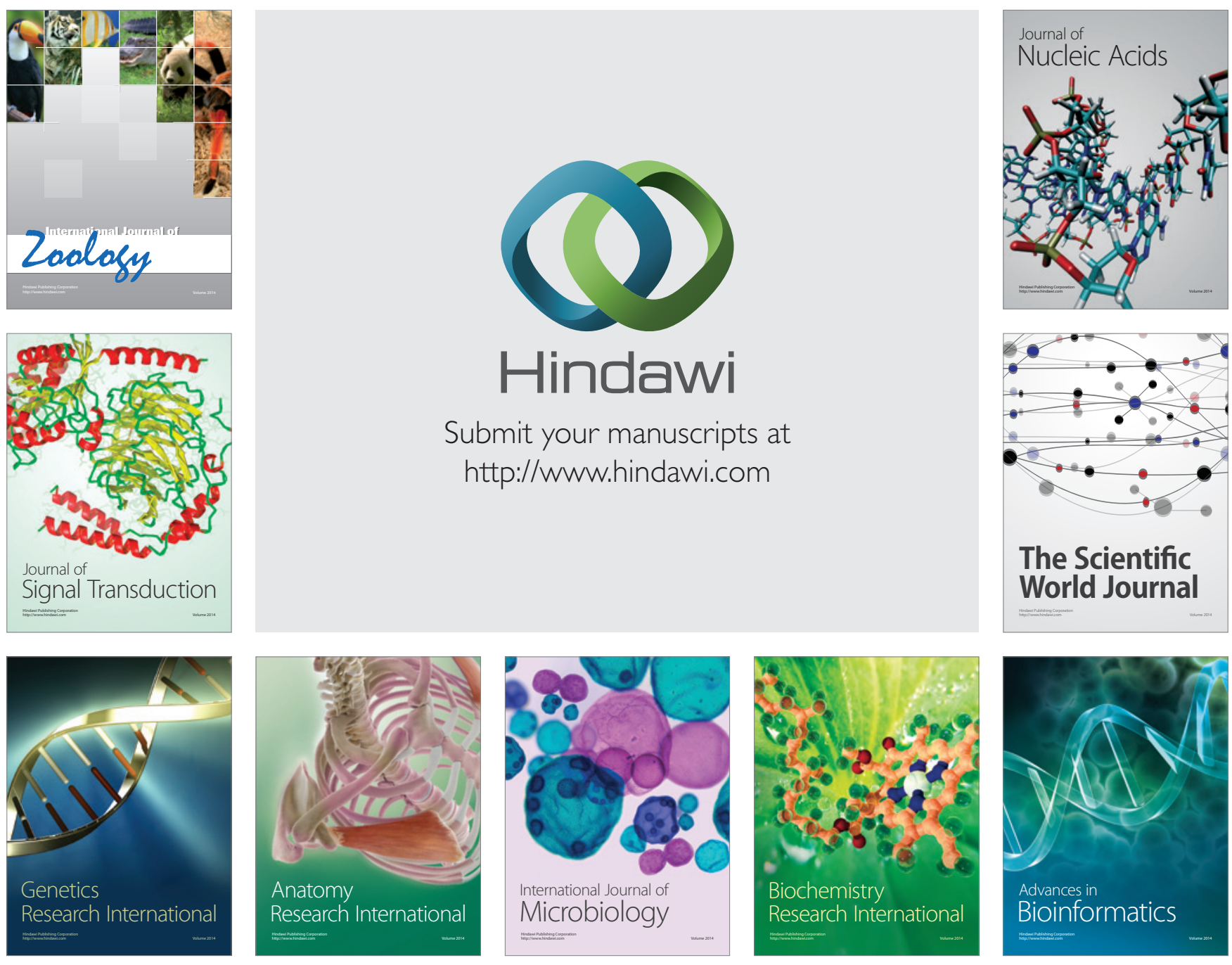

The Scientific World Journal
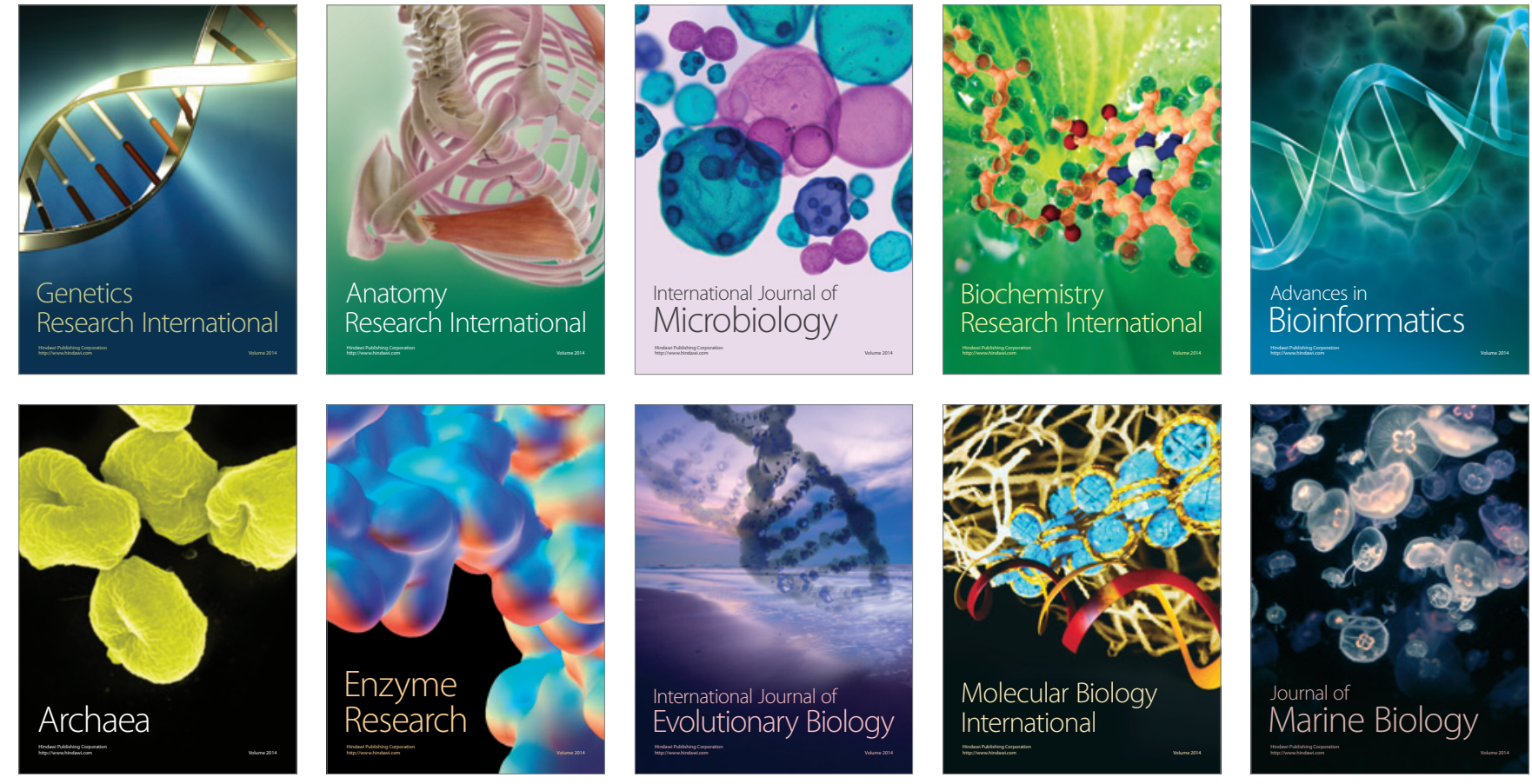